\title{
Developmental exposure to decabromodiphenyl ether (PBDE 209): Effects on thyroid hormone and hepatic enzyme activity in male mouse offspring
}

\author{
Li-Ho Tseng a,b, Mei-Hui Li ${ }^{\text {c }}$, Shinn-Shyong Tsai ${ }^{\text {d }}$, Chia-Wei Lee ${ }^{\text {a }}$, \\ Min-Hsiung Pan ${ }^{\mathrm{e}}$, Wei-Jen Yao ${ }^{\mathrm{f}}$, Ping-Chi Hsu ${ }^{\mathrm{a}, *}$ \\ ${ }^{a}$ Department of Safety, Health and Environmental Engineering, National Kaohsiung First University of Science and Technology, \\ No. 2, Jhuoyue Road, Nanzih District, Kaohsiung City 811, Taiwan \\ ${ }^{\mathrm{b}}$ Department of Occupational Safety and Hygiene, Tajen University, Pingtung, Taiwan \\ ${ }^{\mathrm{c}}$ Environmental Toxicology Lab, Department of Geography, National Taiwan University, Taipei, Taiwan \\ d Department of Veterinary Medicine, National Pingtung University of Science and Technology, Pingtung, Taiwan \\ ${ }^{\mathrm{e}}$ Department of Seafood Science, National Kaohsiung Marine University, Kaohsiung, Taiwan \\ ${ }^{\mathrm{f}}$ Department of Nuclear Medicine, National Cheng Kung University Medical Center, Tainan, Taiwan
}

Received 2 May 2007; received in revised form 25 June 2007; accepted 28 June 2007

Available online 14 August 2007

\begin{abstract}
Decabrominated diphenyl ether (PBDE 209) is the second most used brominated flame retardant (BFRs). Many studies have shown that some of the BFRs act as endocrine disruptors via alterations in thyroid hormone homeostasis and affect development. Little is known about the effect of prenatal exposure to PBDE 209 on the development in male offspring. Using a CD-1 mouse model, we attempt to estimate the possible effect of in utero exposure to PBDE 209 on thyroid hormone and hepatic enzymes activities in male offspring. Pregnant mice were administered different doses of PBDE $209(10,500$, and $1500 \mathrm{mg} / \mathrm{kg} / \mathrm{day})$ or corn oil for controls per gavage from gestational days $0-17$. In adult male offspring whose mothers had been treated with $1500 \mathrm{mg} / \mathrm{kg}$ of PBD 209, hepatic enzyme activity of S9 7-ethoxyresorufin $O$-deethylase (EROD) was weak but significantly increased (54\%). However, no significant changes were observed in S9 4-nitrophenol uridinediphosphate-glucuronosyltransferase (UDPGT) in any of the treatment groups. Serum triiodothyronine (T3) was found to have decreased significantly (ca. $21 \%$ both $10 \mathrm{mg} / \mathrm{kg}$ and $1500 \mathrm{mg} / \mathrm{kg}$ ) in offspring, but not thyroxine (T4). Histopathological examination revealed that prenatal exposure of PBDE 209 might be related with cell swelling of hepatocytes in male offspring and there were mild changes in the thyroid glands in $1500 \mathrm{mg} / \mathrm{kg}$ group. These data demonstrate that PBDE 209 is likely an endocrine disrupter in male mice following exposure during development. Further studies using environmentally relevant doses are needed for hazard identification.

(C) 2007 Elsevier Ltd. All rights reserved.
\end{abstract}

Keywords: Decabrominated diphenyl ether (PBDE 209); Prenatal exposure; Thyroid hormone; Hepatic enzyme activity

\section{Introduction}

Polybrominated diphenyl ethers (PBDEs) are widely used as additive flame retardants in our modern life. PBDEs could easily leach into the environment during products are manufactured, used or disposed of (Sjödin

\footnotetext{
${ }^{*}$ Corresponding author. Tel.: +886 $76011000 \times 2322$ (Off.)/+886 6 2131276 (Res.); fax: +88676011061.

E-mail address: pchsu@ccms.nkfust.edu.tw (P.-C. Hsu).
}

et al., 2001). PBDEs are also widely used in a variety of consumer products and can be found in food, household dust and sewage sludge worldwise. Moreover, several regional studies have indicated time trend increases in concentrations of these substances in humans (Akutsu et al., 2003; Schecter et al., 2005; Fängström et al., 2005) as well as in the environment (Law et al., 2003).

Decabromodiphenyl ether (PBDE 209) is the most important commercially in both production and use of PBDEs (WHO, 1994). Nowadays, PBDE 209 is mostly 
used in high-impact polystyrene plastic used to produce housings for televisions, computers, stereos and other small electronics as well as in upholstery textiles (Hardy, 2002). In south China, higher-brominated diphenyl ethers (including PBDE 209) were detected from the waterbirds egg samples, probably indicating uptake of PBDE 209 by top predators (Lam et al., 2007).

PBDEs show an even closer structural relationship to serum thyroxine (T4) than polychlorinated biphenyls (PCBs), allowing them to bind competitively to thyroid hormone transfer proteins and act as endocrine disrupters (McDonald, 2002). Reduced serum T4 levels accompanied by induced cytochrome P450 activities have been reported in rats prenatally exposed to DE-71 (tetra-, penta- and hexa-bromodiphenyl ether mixtures) (Zhou et al., 2002). Previous studies reported that T4 levels were significantly reduced in mice postnatally exposed to Bromkal 1254 (a PBDE mixture), DE-71, or PBDE 47 (Fowles et al., 1994; Hallgren et al., 2001). Lower-brominated BDE congeners have been found to be more potent plasma T4 reducers than mixtures containing higher-brominated congeners in rat (Zhou et al., 2001). An epidemiological study found that four workers, in a plant manufacturing PBDE 209 and decabromobiphenyl, were found to have clinical hypothyroidism (Bahn et al., 1980). In a plant manufacturing and handling flamer-retarded rubber, workers' serum were found to be exposed to PBDE 209, and traces of PBDE 209 were also found in control group, showing that PBDE 209 was a ubiquitous contaminant (Thuresson et al., 2005).

The findings of previous studies confirm there is significant uptake of PBDE 209 and that it may pose potential risk to human health. One recent study in Indiana, USA found a high association between maternal and fetal cord blood PBDE concentrations (Mazdai et al., 2003). This study shows that PBDEs might be able to enter the fetus through the placenta. If PBDE 209 is transferred as efficiently as those PBDEs through the placenta, it might affect fetal development. However, little is known about PBDE 209 and its possible effects on developmental toxicity, thyroid hormone disruption and hepatic enzymes activities. Therefore, the objective of this study is to investigate adverse effects of maternal and gestational exposure to PBDE 209 on developmental measures and thyroid hormones in CD-1 mice. Hepatic enzyme activities, including 7-ethoxyresorufin $O$-deethylase (EROD) and 4-nitrophenol uridinediphosphate-glucuronosyltransferase (UDPGT), were also measured in these mice to help us understand whether prenatal exposure to PBDE 209 act as endocrine disrupters in male offspring.

\section{Materials and methods}

\subsection{Chemicals}

$2,2^{\prime}, 3,3^{\prime}, 4,4^{\prime}, 5,5^{\prime}, 6,6^{\prime}$-decabrominated diphenyl ether (PBDE 209) (98\%, CAS No. 1163-19-5) was obtained from Sigma-Aldrich (St. Louis, MO, USA). The PBDE 209 stock solution was prepared by mixing the compound with corn oil (Sigma-Aldrich) and sonicating it for $30 \mathrm{~min}$ at room temperature. Other chemicals and reagents used in enzyme assays were obtained from Sigma-Aldrich.

\subsection{Animals}

Adult male (12 weeks old) and female ( 10 weeks old $)$ CD1 mice were provided by the Animal Center of National Cheng Kung University Medical Center (Tainan, Taiwan). The animal chamber was provided with UV sterilized air and maintained at $22 \pm 2{ }^{\circ} \mathrm{C}$ with a constant humidity of $50 \pm 10 \%$ and on a 12-h light/dark cycle. After two weeks of acclimation, breeding was conducted by placing one female into a male's cage. In females, the day of vaginal plug was considered gestation day (GD) 0. Pregnant females were randomly divided into four groups of five mice each and housed individually. Animals from each group were gavaged daily with $0,10,500$, or $1500 \mathrm{mg}$ PBDE $/ \mathrm{kg}$ body weight from GD $0-17$. On GD 17, mothers were checked for the numbers of pups at $0800,1200,1600$, and $2000 \mathrm{~h}$. The quantification of the pups' age began on and started with label postnatal day (PND) 0 on the date of birth. The litter weight, sex, total numbers of offspring and offspring weight were recorded at birth. During the pup's lactation period, developmental landmarks including pinnae detachment, body hair fuzz appearance, incisor eruption, ear opening, and eyes opening day were recorded.

\subsection{Maternal and male offspring evaluations}

Body weights of dams were measured during gestation and lactation periods. After weaning, five dams from each treatment group were euthanized. Their organs including liver, kidney, adrenal, spleen, and ovary were dissected and weighed. Body weights of male offspring were measured every four days. At PND 71, three male offspring per litter were randomly selected. The animal was killed and blood samples were taken and then centrifuged at $2500 \mathrm{rpm}$ for $15 \mathrm{~min}$. Serum samples were collected and stored frozen at $-80^{\circ} \mathrm{C}$ until $\mathrm{T} 4$ and triiodothyronine (T3) were measured. The livers were homogenized in icecold $0.05 \mathrm{M}$ Tris- $\mathrm{KCl}$ buffer $(\mathrm{pH}$ 7.4) and the crude homogenate was centrifuged at $10000 \mathrm{~g}$ for $15 \mathrm{~min}$ at $4{ }^{\circ} \mathrm{C}$ and the supernatant (S9) was preserved at $-80{ }^{\circ} \mathrm{C}$ until hepatic enzyme activities analysis.

\subsection{Hepatic enzyme activity assay}

EROD in the liver $\mathrm{S} 9$ suspension was used as a measurement of cytochrome P450 1A activity and was measured using a modification of a method used by Pohl and Fouts (1980), as previously described (Li et al., 1994). UDPGT activity in the liver S9 suspension was measured using 4nitrophenol as substrates. UDPGT activities toward 4nitrophenol were determined by a modification of the method of Watanabe et al. (1986) as previously described 
(Seo et al., 1995). Each sample was measured in duplicate. Protein content was determined by the Bradford method (1976) using bovine serum albumin as a standard. Each sample was measured in triplicate.

\subsection{Thyroid hormone assay}

Serum total T3 and T4 levels were measured using Coata-Count Total T3 and Total T4 radioimmunoassay kits (Diagnostic Products Corporation, Los Angeles, CA, USA) which were adapted for use with mouse (Modric et al., 1999), according to the manufacturer's instructions. They were performed in the Department of Nuclear Medicine at National Cheng Kung University Hospital Medical Center (Tainan, Taiwan).

\subsection{Histological analysis}

At the time of necropsy, organs, including part of liver and thyroid gland, were removed and fixed in $10 \%$ buffered formalin. Each was processed in an automatic tissue processor and embedded in paraffin. Thin sections were cut at 3-4 $\mathrm{m}$ thickness, stained with hematoxylin and eosin for pathological evaluation under microscope.

\subsection{Statistical analysis}

Data were expressed as means \pm standard deviation (SD) or mean/median (range). All statistical analyses were performed on SPSS 10.0 for Windows. For the analysis of male offspring, the litter was considered the experimental unit. Body weights, organ weights, developmental landmarks, T3, T4, EROD, and UDPGT were compared using one-way analysis of variance (ANOVA) with post hoc comparisons among each group followed by Duncan's multiple comparison tests. A $p$ value of $<0.05$ was considered statistically significant. The repeated-measures ANOVAs were applied to data on mother body weights for gestation and lactation, offspring body weights for preweaning and post-weaning age.

\section{Results}

\subsection{Reproductive parameters}

No significant differences in dams' body weight on GD 0 , gestational length, litter size on PND 1 and PND 4, average pup weight, and average male or female offspring weights in weaning were observed between the control and PBDE 209-treated groups (Table 1).

\subsection{Effects on the development landmarks of F1 generation mice}

In dams treated with PBDE 209, we observed no significant developmental delays in any of development landmarks, including days of pinnae detachment, body hair fuzz appearance, incisor eruption, ear opening, and eyes opening day in control and PBDE 209-treated pups (Table 2).

\subsection{Body and organ weights}

Based on our repeated-measures analysis, the dams treated with PBDE 209 were not found to have significantly different treatment-related measures, compared with the control group, during the gestational period, lactational period, pre-weaning period, and post-weaning period for male offspring. There were no statistically significant interaction effects between age and dosage on trend of body weights (data not shown).

With regard to organ weight measurements for the dams treated with PBDE 209, we found no significant differences in the absolute and relative weights of liver, kidney, adrenal glands, spleen, and ovaries, compared to the controls on weaning day (PND 21) (data not shown). Moreover, we did not find any significant differences in absolute and relative weights of body, brain, thymus, liver, kidney, adrenal glands, and spleen in any of the of male offspring treated with PBDE 209, compared to the controls, on PND 71 (data not shown).

Table 1

Reproductive parameters in dams given PBDE 209 with $10 \mathrm{mg} / \mathrm{kg}, 500 \mathrm{mg} / \mathrm{kg}$, or $1500 \mathrm{mg} / \mathrm{kg}$ and corn oil from gestational day (GD) 0 to GD 17

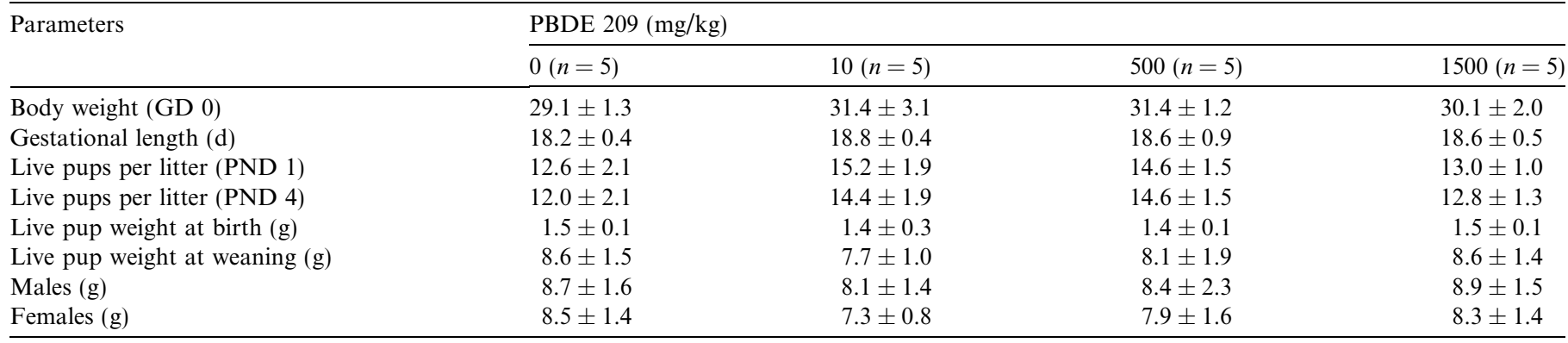

Data are presented as means $\pm \mathrm{SD} ; n$ : number of dams. 
Table 2

Effects of prenatal exposure of PBDE 209 with $10 \mathrm{mg} / \mathrm{kg}, 500 \mathrm{mg} / \mathrm{kg}$, or $1500 \mathrm{mg} / \mathrm{kg}$ of PBDE 209 and corn oil on developmental landmarks in offspring

\begin{tabular}{|c|c|c|c|c|c|c|c|c|}
\hline \multirow[t]{3}{*}{ Parameters } & \multicolumn{8}{|c|}{ PBDE 209 (mg/kg) } \\
\hline & \multicolumn{2}{|l|}{$0(n=5)$} & \multicolumn{2}{|l|}{$10(n=5)$} & \multicolumn{2}{|l|}{$500(n=5)$} & \multicolumn{2}{|l|}{$1500(n=5)$} \\
\hline & Mean/median & Range & Mean/median & Range & Mean/median & Range & Mean/median & Range \\
\hline Body hair fuzz appearance (d) & $6.2 / 6$ & $6-7$ & $5.8 / 5$ & $5-7$ & $6.4 / 6$ & $6-7$ & $6.0 / 6$ & $5-7$ \\
\hline Incisor eruption $(\mathrm{d})$ & $10.6 / 10$ & $10-12$ & $11.0 / 11$ & $10-12$ & $11.6 / 11$ & $11-13$ & $10.8 / 11$ & $10-12$ \\
\hline Eyes opening $(d)$ & $16.2 / 16$ & $16-17$ & $16.0 / 16$ & 16 & $16.2 / 16$ & $16-17$ & $16.0 / 16$ & 16 \\
\hline
\end{tabular}

Data are presented as mean/median and range; $n$ : number of dams.

\subsection{Effects on hepatic enzyme activities}

There was a significant change in S9 EROD activity in the treatment groups. Interestingly, we noted a weak but statistically significant induction (54\%) in S9 EROD activity in the group treated with the highest dose of PBDE 209, compared to controls. There were slight dose-related increases in S9 EROD activity in male offspring treated smaller doses of PBDE 209 (Fig. 1A). However, no significant changes were observed in S9 4-nitrophenol UDPGT activities in any of the treatment groups. (Fig. 1B).
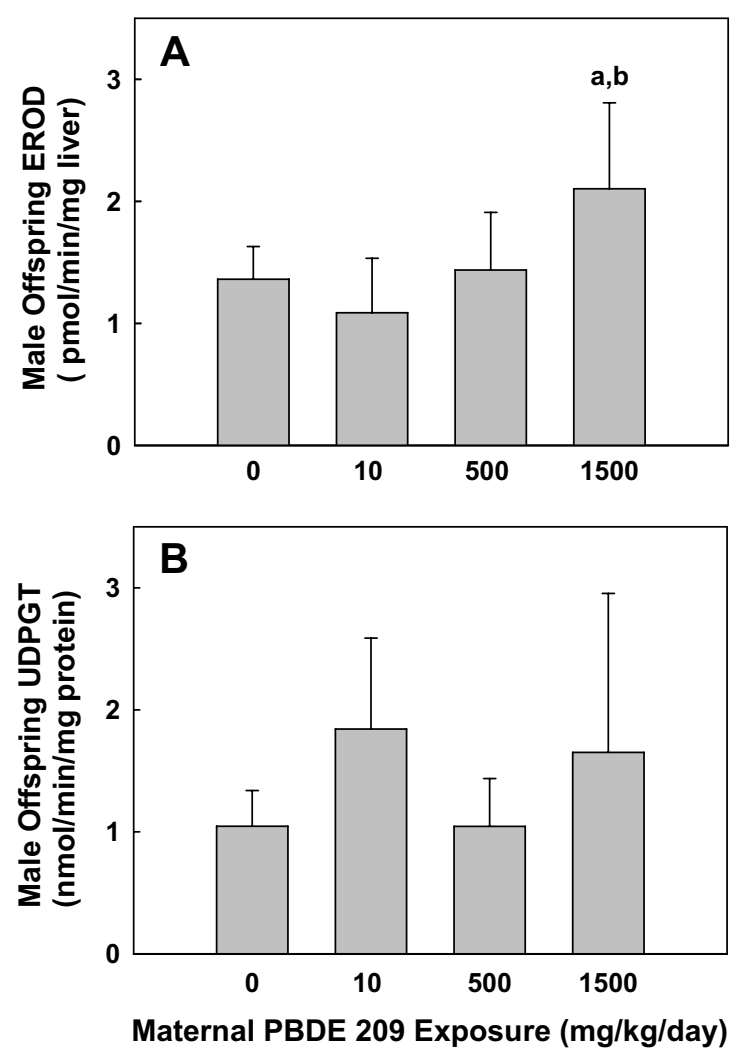

Fig. 1. The effect of prenatal exposure to PBDE 209 on liver microsomal enzyme activities, including S9 7-ethyoxyresorufin $O$-deethylase (EROD) activity (A) and 4-nitrophenol uridinediphosphate-glucuronosyltransferase (UDGPT) activity (B) in male offspring mice. Data are presented as means \pm SD. (a) $p<0.05$ as compared with control group and (b) $p<0.05$ as compared with PBDE $209(10 \mathrm{mg} / \mathrm{kg})$ group.

\subsection{Thyroid hormone levels}

Serum total T3 was found to have decreased significantly $(20.6 \%$ for $10 \mathrm{mg} / \mathrm{kg}$ and $20.7 \%$ for $1500 \mathrm{mg} / \mathrm{kg}$ group) in male offspring on PND 71 (Fig. 2A). However, no significant changes were observed in total $\mathrm{T} 4$ in any of the treatment groups (Fig. 2B).

\subsection{Liver and thyroid histopathology}

The treatment groups were found by histopathological examination to have acute cell swelling of hepatocytes
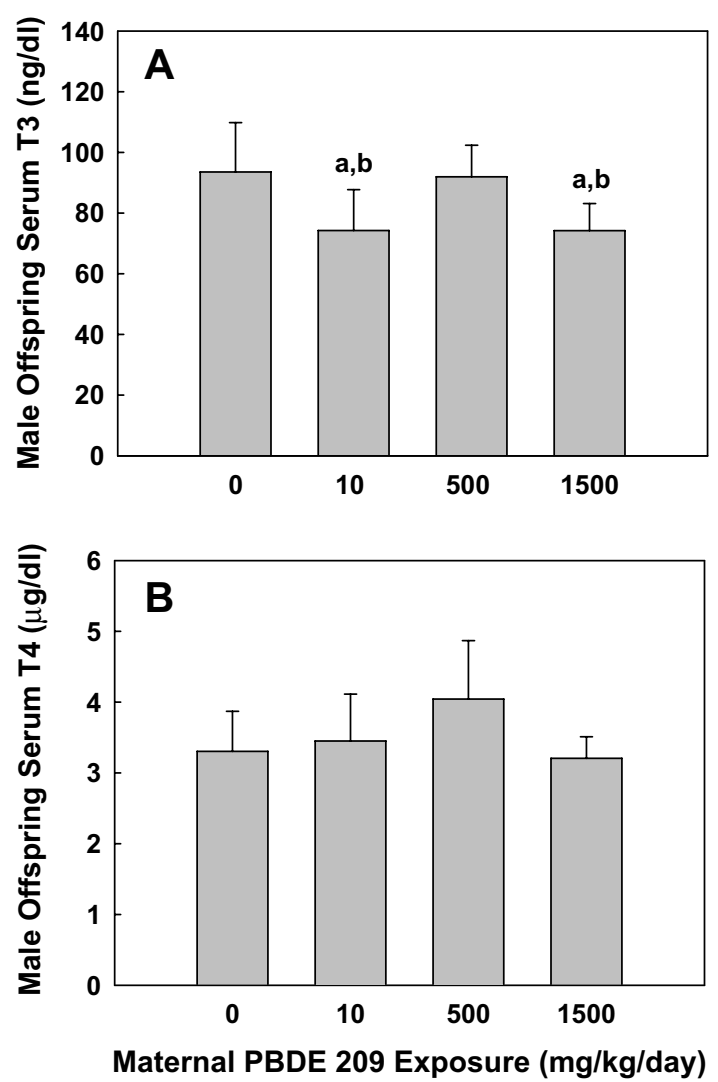

Fig. 2. Serum total triiodothyronine (T3) (A) and total thyroxine (T4) (B) levels in male offspring following prenatal exposure to $10,500,1500 \mathrm{mg} / \mathrm{kg}$ of PBDE 209 or corn oil on postnatal day (PND) 71. Data are presented as means $\pm \mathrm{SD}$. (a) $p<0.05$ as compared with control group and (b) $p<0.05$ as compared with PBDE $209(500 \mathrm{mg} / \mathrm{kg})$ group. 
accompanied associated with pressure occlusion of hepatic sinusoids. This change was prominent and was more pronounced as the dose increased. In the group gavaged with $10 \mathrm{mg} / \mathrm{kg}$ of PBDE 209, the degenerative change was mainly concentrated on the peripheral areas of hepatic lobules (Fig. 3). In the groups treated with $500 \mathrm{mg} / \mathrm{kg}$ and $1500 \mathrm{mg} / \mathrm{kg}$ of PBDE 209, the lobular hepatocytes were found to be diffusely swollen with or without vacuolar degeneration. The liver of the control group was normal. Histology of the thyroid glands showed that only a few acini had slightly enlarged with colloid merely in the $1500 \mathrm{mg} / \mathrm{kg}$ treatment groups, compared to the controls. The normal cuboidal epithelium had dose-dependently transformed into squamous epithelium, the most notable change found in the group treated with $1500 \mathrm{mg} / \mathrm{kg}$ of PDDE 209 (Fig. 4).

\section{Discussion}

In the present study, high doses of PBDE 209 were found to have no effects on mother mice for maternal and gestational parameters. After analysis by repeatedmeasures ANOVAs, we could not find any statistically significant interaction effects of age and dosages on body weight trends. Likewise, no treatment-related effect was detected in pups for fetal body weights, litter size, or development landmarks. Similarly, one recent report found no evidence of maternal or fetal toxicity or developmental
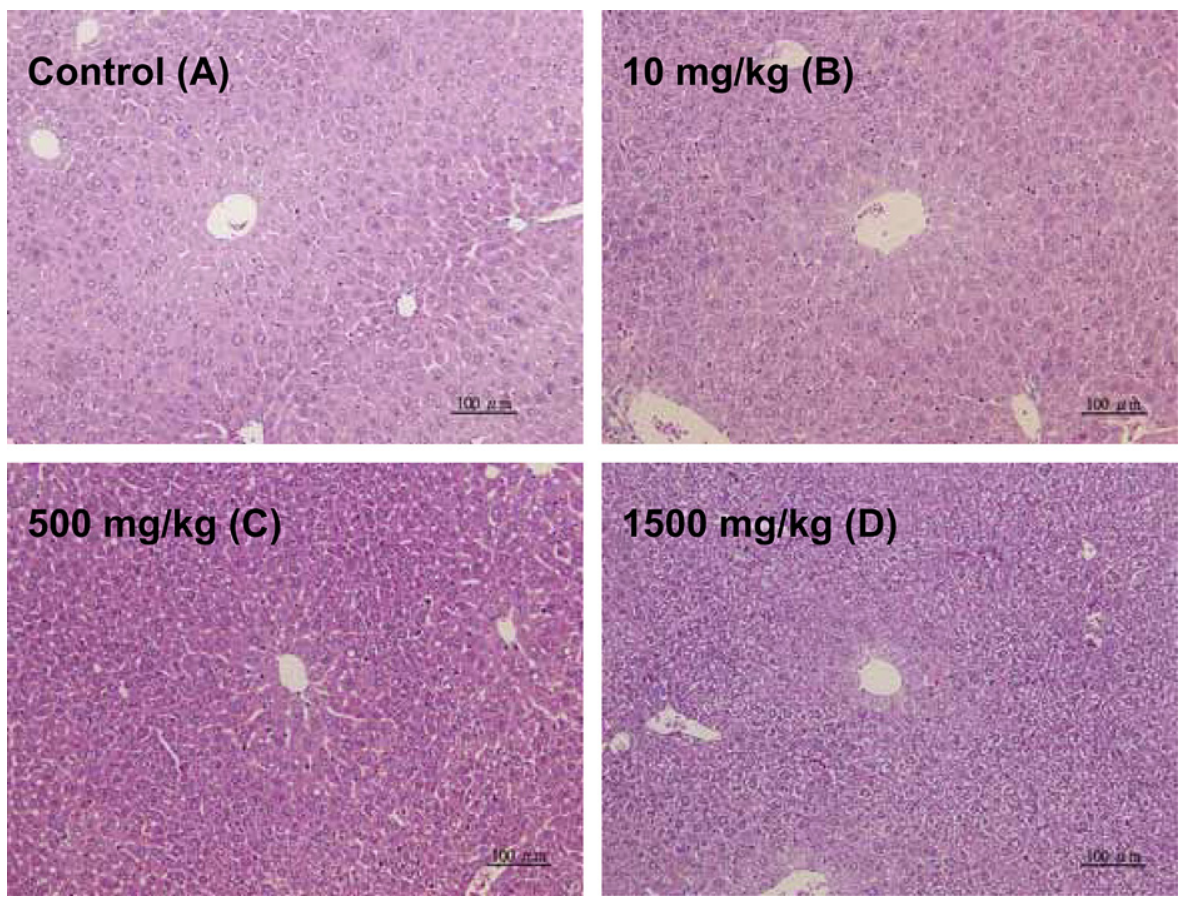

Fig. 3. Normal architecture of liver was found in a male mouse of the control group (A). Acute cell swelling of hepatocytes accompanied by occlusion of blood sinusoids was found mainly in the peripheral zone of liver lobules on the $10 \mathrm{mg} / \mathrm{kg}$ treated mice (B). The hepatocytes shown diffuse cell swelling without any particular distribution pattern in case of $500 \mathrm{mg} / \mathrm{kg}$ (C) and $1500 \mathrm{mg} / \mathrm{kg}$ treated mice (D).
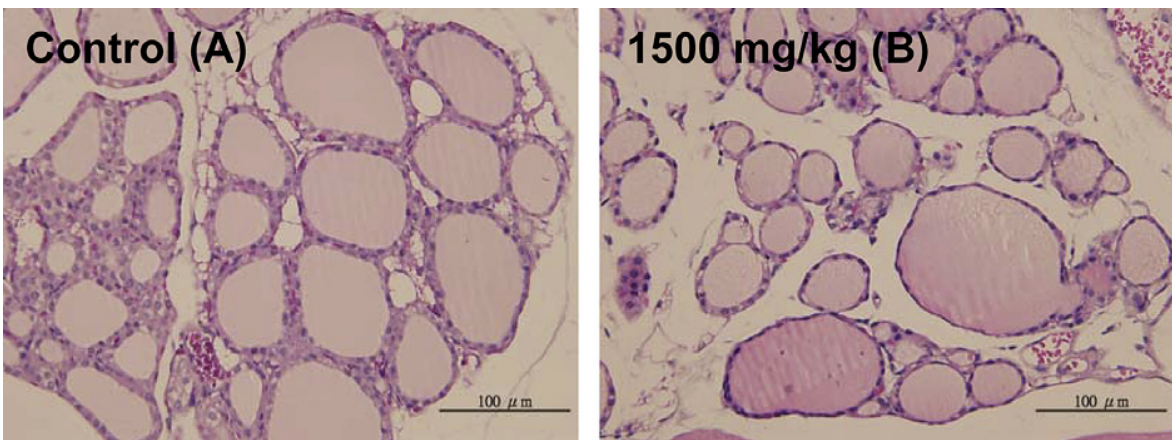

Fig. 4. Thyroid gland was taken from a male mouse of the control group, showing normal architecture. The acinar epithelium was cuboidal in shape with larger follicles and the density of colloid was uniform (A). Thyroid gland from a male mice on the $1500 \mathrm{mg}$ PBDE 209/kg shown slightly enlarged with colloid in a few acini, which were encircled by a layer of squamous epithelium (B). 
effects in a developmental test in the SD rats at $1000 \mathrm{mg}$ of PBDE $209 / \mathrm{kg}$ body weight administered on GD 0-19 (Hardy et al., 2002).

There are only a very limited number of studies on the effects of prenatal exposure of PBDE 209 on hepatic enzyme activities. Carlson (1980) found no hepatic enzyme induction in rats after 14-day postnatal exposure to PBDE 209 with $0.1 \mathrm{mmol} / \mathrm{kg}$ body weight. In addition, Zhou et al. (2001) reported no significant induction in UDPGT and EROD in weaning rats following a 4-day exposure to DE-83R, a commercial PBDE 209 mixture $(>98 \%)$ with different doses from 0.3 to $100 \mathrm{mg} / \mathrm{kg} /$ day. A recent in vitro study by Peters et al. (2006) indicated that no statistically significant induction of CYP1A was observed in the hepatocytes after $48 \mathrm{~h}$ of exposure to all environmentally relevant PBDEs in cynomolgus monkey (Macaca fascicularis) hepatocytes. On the other hand, some studies did find AhR activation by PBDE 77, 100, 153, and 183 in H4IIE cells or primary cell cultures of rat hepatocytes (Behnisch et al., 2003; Chen and Bunce, 2003), however, the observed induction of CYP1A1 was small and occurred only at very high concentrations. In our study, there was also a weak but significant induction in EROD activity in highest dose group and showed slight dose-related increases in male offspring.

PBDEs might be metabolized to hydroxylated PBDEs which may take an important role on thyroid hormone homeostasis. Meerts et al. (2000) found only hydroxylated PBDE congeners capable of displacing T4 from transthyretin, a plasma transport protein. In vitro data suggested that two hydroxylated PBDE congeners were bound to human thyroid hormone receptor- $\alpha 1$ (TR- $\alpha 1)$ and TR- $\beta$, they were also proved to induce both phase I and II metabolic enzymes in liver (Marsh et al., 1998). Prenatal or postnatal exposure of other congeners, including DE-71 (Zhou et al., 2001, 2002; Ellis-Hutchings et al., 2006), DE-79 (Zhou et al., 2001), PBDE 47 (Darnerud et al., 2007) and PBDE mixture (Bromkal 70-5 DE and PBDE 47) (Hallgren et al., 2001) might significantly reduce $\mathrm{T} 4$ levels, while $\mathrm{T} 3$ concentrations were unaffected. We investigated that prenatal exposure to PBDE 209 resulted in significant decrease in serum total T3 on PND 71 in the 10 and $1500 \mathrm{mg} / \mathrm{kg}$ groups. However, there was no statistically significant difference on total T4 among treatment groups. This finding provided another possible effect of higher bromine congener on thyroid hormones homeostasis.

PBDE 209 is reported to be poorly absorbed, rapidly eliminated and marginally distributed to adipose tissue in rats (Mörck et al., 2003). A recent study showed that mice administered a single dose of PBDEs, the concentration of higher bromine congeners (PBDE 153) were much higher than lower bromine congeners (PBDE 47, 99, and 100) in all tissue followed 5-day of exposure (Staskal et al., 2006). On the other hand, this study was found the excretion rate of mice exposed to lower bromine congeners revealed higher excretion rate than higher bromine conge- ner did. It is, therefore, important to consider the differential toxicokinetic parameters associated with higher and lower bromine congeners (congeners of bromine content) as well as species difference when assessing the risk of PBDE to human health.

Though PBDE 209 has long been believed to be only minimally toxic, there is growing evidence that it can be absorbed into the body and that its metabolites might result in behavioral disorders in mice, similar to those caused by PBDE 99 (Viberg et al., 2004). Both fish and rats have been found to break down PBDE 209 into lower-brominated PBDE congeners that are more toxic and more easily absorbed by living things (Mörck et al., 2003; Stapleton et al., 2006). Based on recent evidence, PBDE 209 may be more toxic than previously thought (Tseng et al., 2006) and it can break down into other forms of PBDE that can be both more harmful and more readily absorbed by human.

The lowest- and highest-dose PBDE 209-treated groups had decreases in total T3 but not those treated with medium doses. Interestingly, this result was similar to our recent finding that mice prenatally exposed to $10 \mathrm{mg} / \mathrm{kg}$ and $1500 \mathrm{mg} / \mathrm{kg}$ of PBDE 209 had significant decrease in sperm chromatin DNA integrity in male offspring (Hsu et al., 2006). Many of the endocrine disrupting chemicals appear to have dose-responsive U-shaped and/or inverted U-shaped curves (Putz et al., 2001; Almstrup et al., 2002; Ahn et al., 2005). Interestingly, we did observe a U-shaped trend of 4-nitrophenol UDPGT activity and an inverted Ushaped trend for both serum total T4 and T3. Thought this U-shaped or inverted U-shaped observation is not statistically significant for 4-nitrophenol UDPGT or T4. This finding may be biologically meaningful because hepatic glucuronidation of thyroid hormone has been suggested as a possible mechanism by PHAHs to reduce thyroid hormone in animals (van Birgelen et al., 1995; Morse et al., 1996). Thyroid hormones are important for the normal growth and development of young animals and play an important role in the development of the brain. In mice, PBDE 209 has been reported to be irreversibly neurotoxic and neonatal exposure has been found to result in cognitive deficiencies (Viberg et al., 2003).

Norris et al. (1975) was the first to report the thyrotoxic effects of PBDE compounds in adult rats exposed to octaBDE and PBDE 209 mixtures for 30 days, which he found to result in thyroid hyperplasia. In addition, PBDE 209 has been found to induce statistically significant increases in hepatocellular adenomas and carcinomas (combined) in male mice, but not rats (NTP, 1986). Our histopathological studies found a mild change in the thyroids and a significant change in the livers of the offspring whose mothers had been treated with PBDE 209.

In conclusion, the result of this study finds prenatal exposure to PBDE 209 is able to reduce serum total T3 concentrations in male offspring in low-dose and high-dose group, as well as to induce hepatic EROD activities in male offspring in highest-dose group. Although there were only 
three doses in the dose-response relationship and the limitation of low statistical power, the preliminary results of this study do provide some important information of one most commonly used and environmentally most relevant BFRs for human and ecological risk assessment. Further efforts are required for the analysis of a much larger samples and using environmentally relevant doses of PBDE 209 will be necessary in order to confirm this supposition.

\section{Acknowledgements}

This study was supported by the National Science Council (NSC 94-2314-B-327-001). We wish to thank Ms. Mei-Inn Wang for her technical assistance and Mr. KouTung Huang for his part in the histology analysis.

\section{References}

Ahn, N.S., Hu, H., Park, J.S., Park, J.S., Kim, J.S., An, S., Kong, G., Aruoma, O.I., Lee, Y.S., Kang, K.S., 2005. Molecular mechanisms of the 2,3,7,8-tetrachlorodibenzo- $p$-dioxin-induced inverted $\mathrm{U}$-shaped dose responsiveness in anchorage independent growth and cell proliferation of human breast epithelial cells with stem cell characteristics. Mutat. Res. 579, 189-199.

Akutsu, K., Kitagawa, M., Nakazawa, H., Makino, T., Iwazaki, K., Oda, H., Hori, S., 2003. Time-trend (1973-2000) of polybrominated diphenyl ethers in Japanese mother's milk. Chemosphere 53, 645654.

Almstrup, K., Fernandez, M.F., Petersen, J.H., Olea, N., Skakkebaek, N.E., Leffers, H., 2002. Dual effects of phytoestrogens result in U-shaped dose-response curves. Environ. Health Perspect. 110, 743748.

Bahn, A.K., Mills, J.L., Snyder, P.J., Gann, P.H., Houten, L., Bialik, O., Hollmann, L., Utiger, R.D., 1980. Hypothyroidism in workers exposed to polybrominated biphenyls. N. Engl. J. Med. 302, 31-33.

Behnisch, P.A., Hosoe, K., Sakai, S., 2003. Brominated dioxin-like compounds: in vitro assessment in comparison to classical dioxin-like compounds and other polyaromatic compounds. Environ. Int. 29, 861-877.

Bradford, M.M., 1976. A rapid and sensitive method for the quantitation of microgram quantities of protein utilizing the principle of proteindye binding. Anal. Biochem. 72, 248-254.

Carlson, G.P., 1980. Induction of xenobiotic metabolism in rats by shortterm administration of brominated diphenyl ethers. Toxicol. Lett. 5, $19-25$.

Chen, G., Bunce, N.J., 2003. Polybrominated diphenyl ethers as Ah receptor agonists and antagonists. Toxicol. Sci. 76, 310-320.

Darnerud, P.O., Aune, M., Larsson, L., Hallgren, S., 2007. Plasma PBDE and thyroxine levels in rats exposed to Bromkal or BDE-47. Chemosphere 67, S386-S392.

Ellis-Hutchings, R.G., Cherr, G.N., Hanna, L.A., Keen, C.L., 2006. Polybrominated diphenyl ether (PBDE)-induced alterations in vitamin A and thyroid hormone concentrations in the rat during lactation and early postnatal development. Toxicol. Appl. Pharmacol. 215, 135-145.

Fängström, B., Hovander, L., Bignert, A., Athanassiadis, I., Linderholm, L., Grandjean, P., Weihe, P., Bergman, A., 2005. Concentrations of polybrominated diphenyl ethers, polychlorinated biphenyls, and polychlorobiphenylols in serum from pregnant Faroese women and their children 7 years later. Environ. Sci. Technol. 39, 9457-9463.

Fowles, J.R., Fairbrother, A., Baecher-Steppan, L., Kerkvliet, N.I., 1994. Immunologic and endocrine effects of the flame-retardant pentabromodiphenyl ether (DE-71) in C57BL/6J mice. Toxicology 86, 49-61.

Hallgren, S., Sinjari, T., Hakansson, H., Darnerud, P.O., 2001. Effects of polybrominated diphenyl ethers (PBDEs) and polychlorinated biphe- nyls (PCBs) on thyroid hormone and vitamin A levels in rats and mice. Arch. Toxicol. 75, 200-208.

Hardy, M.L., 2002. A comparison of the properties of the major commercial PBDPO/PBDE product to those of major PBB and PCB products. Chemosphere 46, 717-728.

Hardy, M.L., Schroeder, R., Biesemeier, J., Manor, O., 2002. Prenatal oral (gavage) developmental toxicity study of decabromodiphenyl oxide in rats. Int. J. Toxicol. 21, 83-91.

Hsu, P.C., Tseng, L.H., Lee, C.W., 2006. Effects of prenatal exposure of decabrominated diphenyl ether (PBDE 209) on reproductive system in male mice. Organohalogen Compd. 68, 1547-1550.

Lam, J.C., Kajiwara, N., Ramu, K., Tanabe, S., Lam, P.K., 2007. Assessment of polybrominated diphenyl ethers in eggs of waterbirds from South China. Environ. Pollut. 148, 258-267.

Law, R.J., Alaee, M., Allchin, C.R., Boon, J.P., Lebeuf, M., Lepom, P., Stern, G.A., 2003. Levels and trends of polybrominated diphenylethers and other brominated flame retardants in wildlife. Environ. Int. 29, $757-770$.

Li, M.H., Zhao, Y.D., Hansen, L.G., 1994. Multiple dose toxicokinetic influence on the estrogenicity of $2,2^{\prime}, 4,4^{\prime}, 5,5^{\prime}$-hexachlorobiphenyl. Bull. Environ. Contam. Toxicol. 53, 583-590.

Marsh, G., Bergman, A., Bladh, L.G., Gillner, M., Jakobsson, E., 1998. Synthesis of $p$-hydroxybromodiphenyl ethers and binding to the thyroid receptor. Organohalogen Compd. 37, 305-308.

Mazdai, A., Dodder, N.G., Abernathy, M.P., Hites, R.A., Bigsby, R.M., 2003. Polybrominated diphenyl ethers in maternal and fetal blood samples. Environ. Health Perspect. 111, 1249-1252.

McDonald, T.A., 2002. A perspective on the potential health risks of PBDEs. Chemosphere 46, 745-755.

Meerts, I.A., van Zanden, J.J., Luijks, E.A., van Leeuwen-Bol, I., Marsh, G., Jakobsson, E., Bergman, A., Brouwer, A., 2000. Potent competitive interactions of some brominated flame retardants and related compounds with human transthyretin in vitro. Toxicol. Sci. 56, 95104.

Modric, T., Rajkumar, K., Murphy, L.J., 1999. Thyroid gland function and growth in IGF binding protein-1 transgenic mice. Eur. J. Endocrinol. 141, 149-159.

Mörck, A., Hakk, H., Örn, U., Klasson, W.E., 2003. Decabromodiphenyl ether in the rat: absorption, distribution, metabolism, and excretion. Drug Metab. Dispos. 31, 900-907.

Morse, D.C., Wehler, E.K., Wesseling, W., Koeman, J.H., Brouwer, A., 1996. Alterations in rat brain thyroid hormone status following preand postnatal exposure to polychlorinated biphenyls (Aroclor 1254). Toxicol. Appl. Pharmacol. 136, 269-279.

National Toxicology Program (NTP), 1986. Toxicology and Carcinogenesis Studies of Decabromodiphenyl Oxide (CAS No.1163-19-5) in F344/N Rats and B6C3F1 Mice (Feed Studies). NTP Technical Report Series No. 398, Research Triangle Park, NC, US Department of Health and Human Senices, Public Health Senice, National Institute of Health.

Norris, J.M., Kociba, R.J., Schwetz, B.A., Rose, J.Q., Humiston, C.G., Jewett, G.L., Gehring, P.J., Mailhes, J.B., 1975. Toxicology of octabromobiphenyl and decabromodiphenyl oxide. Environ. Health Perspect. 11, 153-161.

Peters, A.K., Sanderson, J.T., Bergman, A., van den Berg, M., 2006. Antagonism of TCDD-induced ethoxyresorufin- $O$-deethylation activity by polybrominated diphenyl ethers (PBDEs) in primary cynomolgus monkey (Macaca fascicularis) hepatocytes. Toxicol. Lett. 164, 123-132.

Pohl, R.J., Fouts, J.R., 1980. A rapid method for assaying the metabolism of 7-ethoxyresorufin by microsomal subcellular fractions. Anal. Biochem. 107, 150-155.

Putz, O., Schwartz, C.B., LeBlanc, G.A., Cooper, R.L., Prins, G.S., 2001. Neonatal low- and high-dose exposure to estradiol benzoate in the male rat: II. Effects on male puberty and the reproductive tract. Biol. Reprod. 65, 1506-1517.

Schecter, A., Papke, O., Joseph, J.E., Tung, K.C., 2005. Polybrominated diphenyl ethers (PBDEs) in U.S. computers and domestic carpet 
vacuuming: possible sources of human exposure. J. Toxicol. Environ. Health A 68, 501-513.

Seo, B.W., Li, M.H., Hansen, L.G., Moore, R.W., Peterson, R.E., Schantz, S.L., 1995. Effects of gestational and lactational exposure to coplanar polychlorinated biphenyl (PCB) congeners or 2,3,7,8-tetrachlorodibenzo- $p$-dioxin (TCDD) on thyroid hormone concentrations in weanling rats. Toxicol. Lett. 78, 253-262.

Sjödin, A., Carlsson, H., Thuresson, K., Sjölin, S., Bergman, A., Östman, C., 2001. Flame retardants in indoor air at an electronics recycling plant and at other work environments. Environ. Sci. Technol. 35, 448454.

Stapleton, H.M., Brazil, B., Holbrook, R.D., Mitchelmore, C.L., Benedict, R., Konstantinov, A., Potter, D., 2006. In vivo and in vitro debromination of decabromodiphenyl ether (BDE 209) by juvenile rainbow trout and common carp. Environ. Sci. Technol. 40, 46534658.

Staskal, D.F., Hakk, H., Bauer, D., Diliberto, J.J., Birnbaum, L.S., 2006. Toxicokinetics of polybrominated diphenyl ether congeners 47,99 , 100, and 153 in mice. Toxicol. Sci. 94, 28-37.

Thuresson, K., Bergman, A., Jakobsson, K., 2005. Occupational exposure to commercial decabromodiphenyl ether in workers manufacturing or handling flame-retarded rubber. Environ. Sci. Technol. 39, 1980-1986.

Tseng, L.H., Lee, C.W., Pan, M.H., Tsai, S.S., Li, M.H., Chen, J.R., Lay, J.J., Hsu, P.C., 2006. Postnatal exposure of the male mouse to $2,2^{\prime}, 3,3^{\prime}, 4,4^{\prime}, 5,5^{\prime}, 6,6^{\prime}$-decabrominated diphenyl ether: decreased epididymal sperm functions without alterations in DNA content and histology in testis. Toxicology 224, 33-43.
Van Birgelen, A.P., Smit, E.A., Kampen, I.M., Groeneveld, C.N., Fase, K.M., Van der Kolk, J., Poiger, H., Van den Berg, M., Koeman, J.H., Brouwer, A., 1995. Subchronic effects of 2,3,7,8-TCDD or PCBs on thyroid hormone metabolism: use in risk assessment. Eur. J. Pharmacol. 293, 77-85.

Viberg, H., Fredriksson, A., Jakobsson, E., Orn, U., Eriksson, P., 2003. Neurobehavioral derangements in adult mice receiving decabrominated diphenyl ether (PBDE 209) during a defined period of neonatal brain development. Toxicol. Sci. 76, 112-120.

Viberg, H., Fredriksson, A., Eriksson, P., 2004. Investigations of strain and/or gender differences in developmental neurotoxic effects of polybrominated diphenyl ethers in mice. Toxicol. Sci. 81, 344 353.

Watanabe, H.K., Hoskins, B., Ho, I.K., 1986. Selective inhibitory effect of organophosphates on UDP-glucuronyl transferase activities in rat liver microsomes. Biochem. Pharmacol. 35, 455-460.

World Health Organization (WHO). 1994. Brominated diphenyl ethers. International Programme on Chemical Safety, Environmental Health Criteria Document Number 162. Geneva, World Health Organization.

Zhou, T., Ross, D.G., DeVito, M.J., Crofton, K.M., 2001. Effects of short-term in vivo exposure to polybrominated diphenyl ethers on thyroid hormones and hepatic enzyme activities in weanling rats. Toxicol. Sci. 61, 76-82.

Zhou, T., Taylor, M.M., DeVito, M.J., Crofton, K.M., 2002. Developmental exposure to brominated diphenyl ethers results in thyroid hormone disruption. Toxicol. Sci. 66, 105-116. 